\title{
KNOWLEDGE AND PRACTICES OF HEALTH CARE PROFESSIONALS WITH REGARD TO NOSOCOMIAL INFECTIONS AT A MEDICAL COLLEGE AT GOA, INDIA- A CROSS-SECTIONAL STUDY
}

\author{
Nitin Y. Dhupdale1, Parnika Singh², Jagadish Cacodcar ${ }^{3}$
}

${ }_{1}^{1}$ Lecturer, Department of Preventive and Social Medicine, Goa Medical College, Bambolim, Goa, India.

${ }^{2}$ Final MBBS Student, Goa Medical College, Bambolim, Goa, India.

3 Professor and HOD, Department of Preventive and Social Medicine, Goa Medical College, Bambolim, Goa, India. ABSTRACT

\section{BACKGROUND}

Nosocomial infections (NI) are acquired during hospitalization which are not present at the time of admission to a hospital. Present study is aimed at bridging this knowledge gap which will benefit the policy makers to safeguard health of professionals and patients.

\section{MATERIALS AND METHODS}

A cross-sectional study was conducted on a purposive sample of 100 doctors. The data was obtained in the form of selfadministered questionnaire.

\section{RESULTS}

All participants were familiar with NI. UTI (28\%) was reported as commonest NI. Pseudomonas (28\%) was identified as commonest causative agent of NI. 94\% medical professionals believed that they need training in NI. 78\% of medical professionals reported regular hand washing before and after examination of patient.

\section{CONCLUSION}

Doctors who participated in study had excellent knowledge about the NI. Some deficiencies in the practices such as not ensuring sterile conditions, exiting operation room along with sterile footwear were of concern.

\section{KEY WORDS}

Nosocomial Infections, Hospital Acquired Infections, Knowledge, Practices, Doctors, Goa, India

HOW TO CITE THIS ARTICLE: Dhupdale NY, Singh P, Cacodcar J. Knowledge and practices of health care professionals with regard to nosocomial infections at a medical college at Goa, India- a cross-sectional study. J. Evolution Med. Dent. Sci. 2019;8(12):902-906, DOI: $10.14260 /$ jemds/2019/201

\section{BACKGROUND}

Nosocomial Infections (NI) also known as hospitalacquired/associated infections (HAI) are acquired during hospitalization, which are not present or incubating at the time of admission to a hospital. These infections typically occur after 48 hours of admission. The commonest organisms implicated include Staphylococcus aureus, coagulasenegative staphylococci, enterococci, Enterobacteriaceae, multidrug resistant E. coli, Staphylococcus aureus, Pseudomonas, Enterobacter, Acinetobacter, Klebsiella, etc. Overcrowding and transfer of patients within hospital units and build-up of susceptible patients could contribute to the development of Nosocomial Infections. As per the published literature, the common Nosocomial Infections are Urinary infections, Surgical site infections, Nosocomial bacteraemia and other infections. ${ }^{1}$ Another reason for the contamination of clean surgeries with hospital staphylococcus was delay in operation of more than 24 hours of admission ${ }^{2}$ As per World Health Organization (WHO) estimates, around 1.4 million people worldwide suffer from infectious complications acquired in hospital.

'Financial or Other Competing Interest': None.

Submission 16-01-2019, Peer Review 10-03-2019,

Acceptance 16-03-2019, Published 25-03-2019.

Corresponding Author:

Dr. Nitin Y. Dhupdale,

Lecturer, Department of Preventive and Social Medicine,

Goa Medical College, Bambolim, Goa, India.

E-mail: nydhupdale@gmail.com

Nosocomial Infections also cause lot of economic losses to the victims in addition to physical and mental agony. ${ }^{3}$ The HAI infection rates in India ranged from $4.4 \%$ to $83.09 \% .4,5$

In a study conducted in Goa, overall Nosocomial Infections rate was $33.93 \pm 4.16$ infections per 100 patients. The commonest Nosocomial Infections were Urinary tract infections (UTI), followed by surgical site infections, wound infections and nosocomial pneumonia. $70 \%$ of the bacteria isolated were resistant to antibiotics tested. These microorganisms were found to be sensitive to amikacin, cefoperazone-sulbactam, methicillin, co-trimoxazole, teicoplanin, vancomycin and rifampicin. MRSA was isolated in $71.4 \%$ of patients. ${ }^{6}$

There is paucity of studies conducted on the knowledge and practice among young medical professionals towards Nosocomial Infections in Goa, India. The present study was aimed at bridging this knowledge gap so that this important issue could be addressed in an adequate and timely manner which will benefit the policy makers to safe guard the health of professionals and their patients.

\section{Objectives}

The Objectives of this Study were as follows-

1. To determine the level of knowledge of health care professionals on Nosocomial Infections.

2. To determine the practices adopted in daily clinical practice towards their control. 


\section{MATERIALS AND METHODS}

\section{Study Setting}

The Goa Medical College Hospital is the only tertiary care and teaching hospital in the State of Goa.

\section{Study Design}

A cross-sectional study design was employed for data collection.

\section{Study Participants}

The study participants comprised of young medical professionals (Senior Resident doctors, Junior Resident doctors and Medical Interns) working at Goa Medical College and Hospital. The work experience of the doctors varied. Senior Resident doctors had an experience of at least 3 years. Junior Resident Doctors had an experience between 1-3 years while medical Interns had less than one year of experience.

\section{Sampling}

A purposive sampling method was utilized for the data collection. A total of 100 young medical professionals were enrolled in the study. A total of 51 Resident doctors and 49 Medical Interns were enrolled after obtaining their verbal consent.

\section{Ethical Issues}

The study protocol was approved by the Institutional Ethics Committee of Goa Medical College before the commencement of data collection (Reference No: GMC/IEC/AL-18; Dated: 12/12/2016).

\section{Data Collection}

The data was collected by using a structured questionnaire. The study questionnaire was self-administered to study participants.

\section{Data Entry and Analysis}

The data was entered into EpiData software (Version 3.1) ${ }^{7}$ and frequency tables were generated by using SPSS software (Licensed Version 23, Customer ID 227011). The results are presented in tables using proportions.

\section{RESULTS}

\section{Socio-Demographic Details}

Of the total 100 young medical professionals who completed the study questionnaires, $44 \%$ were Males and $56 \%$ were Females. The study participants comprised of Medical Interns (49\%), Junior Resident doctors (41\%) and Senior Resident doctors $(10 \%)$ (Table1). The mean age of the doctors was $23.9375 \pm 1.90740$ years. These doctors worked in Departments of Medicine, Surgery, OBG, Dermatology, ENT, Ophthalmology, Pulmonary Medicine, Paediatrics and Community Medicine [Table 1]. All the doctors interviewed were familiar with Nosocomial Infections.

\section{Knowledge Regarding Nosocomial Infections in Clinical Practice}

The various types of nosocomial infections reported were UTI (28\%), post-operative wound infections $(25 \%)$, respiratory tract infections (17\%), pneumonia (15\%), Ventilator Associated Pneumonia (11\%), and Pyoderma (1\%) (Table 2).

\begin{tabular}{|c|c|c|c|}
\hline Variable & Categories & Frequency & Percent \\
\hline $\begin{array}{c}\text { Sex } \\
\text { (N=100) }\end{array}$ & Male & 44 & 44.0 \\
\cline { 2 - 4 } & Female & 56 & 56.0 \\
\hline \multirow{4}{*}{$\begin{array}{c}\text { Designation } \\
\text { N=100) }\end{array}$} & $\begin{array}{c}\text { Medical Interns } \\
\text { Junior Resident } \\
\text { Doctors }\end{array}$ & 49 & 49.0 \\
\cline { 2 - 4 } & $\begin{array}{c}\text { Senior Resident } \\
\text { Doctors }\end{array}$ & 10 & 41.0 \\
\hline \multirow{4}{*}{$\begin{array}{c}\text { Pulmonary } \\
\text { Medicine }\end{array}$} & 2 & 2.0 \\
\cline { 2 - 4 } (N=100) & $\begin{array}{c}\text { Community } \\
\text { Medicine }\end{array}$ & 10 & 10.0 \\
\cline { 2 - 4 } & ENT & 8 & 8.0 \\
\cline { 2 - 4 } & Ophthalmology & 5 & 5.0 \\
\cline { 2 - 4 } & Medicine & 20 & 20.0 \\
\cline { 2 - 4 } & $\begin{array}{c}\text { Obstetrics and } \\
\text { Gynecology }\end{array}$ & 22 & 22.0 \\
\cline { 2 - 4 } & Pediatrics & 7 & 7.0 \\
\cline { 2 - 4 } & Dermatology & 7 & 7.0 \\
\cline { 2 - 4 } & Surgery & 19 & 19.0 \\
\hline \multicolumn{1}{|c|}{ Table 1. Demographic Variables of Study Population } \\
\hline
\end{tabular}

\begin{tabular}{|c|c|c|c|}
\hline Variables & Categories & Frequency & Percent \\
\hline \multirow{7}{*}{$\begin{array}{l}\text { Nosocomial } \\
\text { Infections } \\
(\mathrm{N}=100)\end{array}$} & $\begin{array}{c}\text { Post-Operative } \\
\text { Wound Infections }\end{array}$ & 25 & 25.0 \\
\hline & $\begin{array}{l}\text { Urinary Tract } \\
\text { Infections }\end{array}$ & 28 & 28.0 \\
\hline & \begin{tabular}{|c|}
$\begin{array}{c}\text { Ventilator Associated } \\
\text { Pneumonia }\end{array}$ \\
\end{tabular} & 11 & 11.0 \\
\hline & \begin{tabular}{|c|} 
Respiratory Tract \\
Infections
\end{tabular} & 17 & 17.0 \\
\hline & Pyodermas & 1 & 1.0 \\
\hline & Pneumonias & 15 & 15.0 \\
\hline & Not Specified & 3 & 3.0 \\
\hline \multirow{7}{*}{$\begin{array}{l}\text { Pathogens } \\
(\mathrm{N}=100)\end{array}$} & Pseudomonas & 28 & 28.0 \\
\hline & $\begin{array}{c}\text { Acinetobacter } \\
\text { baumannii }\end{array}$ & 17 & 17.0 \\
\hline & $\begin{array}{c}\text { Methicillin Resistant } \\
\text { Staphylococcus } \\
\text { aureus } \\
\end{array}$ & 1 & 1.0 \\
\hline & Streptococcus & 11 & 11.0 \\
\hline & $\begin{array}{c}\text { Staphylococcus } \\
\text { aureus }\end{array}$ & 25 & 25.0 \\
\hline & Escherichia coli & 15 & 15.0 \\
\hline & Not Specified & 3 & 3.0 \\
\hline \multirow{7}{*}{$\begin{array}{c}\text { Modes of } \\
\text { Transmission } \\
(\mathrm{N}=100)\end{array}$} & \begin{tabular}{|c|} 
Fomites \\
\end{tabular} & 10 & 10.0 \\
\hline & Unsterile Instruments & 14 & 14.0 \\
\hline & \begin{tabular}{|c|} 
Improper \\
Sterilization \\
Technique \\
\end{tabular} & 4 & 4.0 \\
\hline & $\begin{array}{c}\text { Contact with Patients } \\
\text { \& Staff }\end{array}$ & 34 & 34.0 \\
\hline & \begin{tabular}{|c|}
$\begin{array}{c}\text { Aerosols from } \\
\text { Patients }\end{array}$ \\
\end{tabular} & 27 & 27.0 \\
\hline & Infected Catheters & 8 & 8.0 \\
\hline & Dirty linen & 3 & 3.0 \\
\hline
\end{tabular}

The most prominent pathogen causing Nosocomial Infections reported by the doctors was Pseudomonas (28\%) as shown in Table 2. The commonest mode of transmission reported by study participants was direct contact with patients and staff $(34 \%)$. The various other modes of transmission are listed in Table 2. All doctors were aware of universal safety precautions and believed that Nosocomial 
Infections are a major concern for them in their practice and also concurred for its inclusion in Medical education syllabus.

\section{Reported Practices Related to Prevention of Nosocomial Infections.}

About, 94\% medical professionals believed that training is required to improve their skills as regard to Nosocomial Infections, whereas $6 \%$ did not felt this need. Of the total, $74 \%$ medical professionals believed that the Institution has taken appropriate actions for prevention of Nosocomial Infections, while $26 \%$ did not agree to the same. According to $41 \%$ medical professionals', due importance is given to universal safety precautions, however $59 \%$ felt that there was inadequate importance. A total of $78 \%$ of medical professionals reported regular hand washing before and after examination of patient as shown in Table 3.

\begin{tabular}{|c|c|c|c|}
\hline Variable & Categories & Frequency & Percentage \\
\hline \multirow{2}{*}{$\begin{array}{c}\text { Wash hands } \\
\text { before and after } \\
\text { patient } \\
\text { examination } \\
(\mathrm{N}=100) \\
\end{array}$} & Regularly & 78 & 78.0 \\
\hline & Sometimes & 22 & 22.0 \\
\hline \multirow{4}{*}{$\begin{array}{c}\text { Ensure sterile } \\
\text { conditions while } \\
\text { catheterization } \\
(\mathrm{N}=100)\end{array}$} & Regularly & 70 & 70.0 \\
\hline & Sometimes & 28 & 28.0 \\
\hline & Never & 1 & 1.0 \\
\hline & Not specified & 1 & 1.0 \\
\hline \multirow{3}{*}{\begin{tabular}{|c|} 
Exit sterile \\
portion of OT \\
with gown and \\
slippers $(\mathrm{N}=100)$ \\
\end{tabular}} & Regularly & 7 & 7.0 \\
\hline & Sometimes & 55 & 55.0 \\
\hline & Never & 38 & 38.0 \\
\hline \multirow{2}{*}{\begin{tabular}{|c|} 
Wear gloves \\
while dressing \\
post-operative \\
wounds $(\mathrm{N}=100)$
\end{tabular}} & Regularly & 93 & 93.0 \\
\hline & Sometimes & 7 & 7.0 \\
\hline \multirow{4}{*}{\begin{tabular}{|c|}
$\begin{array}{c}\text { Recommend } \\
\text { isolation of } \\
\text { patients with } \\
\text { infection }(\mathrm{N}=100)\end{array}$ \\
\end{tabular}} & Regularly & 57 & 57.0 \\
\hline & Sometimes & 39 & 39.0 \\
\hline & Never & 3 & 3.0 \\
\hline & Not specified & 1 & 1.0 \\
\hline \multicolumn{4}{|c|}{$\begin{array}{c}\text { Table 3. Nosocomial Infections Related Preventive } \\
\text { Practices Among Study Participants }\end{array}$} \\
\hline
\end{tabular}

\section{Clinical Decisions Adopted to Control Nosocomial Infections}

Around $70 \%$ of study participants reported that they regularly ensure sterile conditions while performing catheterization procedure as noted in Table 3. About $7 \%$ of doctors exited sterile portion of Operation Theatre (OT) along with OT foot wares and gowns regularly while 55\% did so occasionally (Table 3). A total of $93 \%$ doctors wear gloves regularly for dressing while $7 \%$ did it sometimes (Table 3).

A total of $57 \%$ of doctors recommended isolation of patient with Nosocomial Infections regularly and 39\% recommended isolation only sometimes (Table 3). About, $82 \%$ regularly sent patient's tissue or fluid for culture and drug-sensitivity testing (Table 3). Commonest nosocomial infection encountered by the medical professionals found frequently in daily practice is shown in (Table 4). Majority of doctors mentioned Vancomycin to treat Nosocomial Infections as listed in Table 4.

\begin{tabular}{|c|c|c|c|}
\hline Variable & Frequency & Frequency & Percent \\
\hline \multirow{3}{*}{$\begin{array}{c}\text { Perform culture } \\
\text { and sensitivity to } \\
\text { isolate } \\
\text { bacteria }(\mathrm{N}=100)\end{array}$} & Regularly & 82 & 82.0 \\
\hline & Sometimes & 17 & 17.0 \\
\hline & Never & 1 & 1.0 \\
\hline \multirow{6}{*}{$\begin{array}{c}\text { Commonest } \\
\text { nosocomial } \\
\text { infection } \\
\text { observed in } \\
\text { practice }(\mathrm{N}=100)\end{array}$} & $\begin{array}{l}\text { Post-operative } \\
\text { wound infection }\end{array}$ & 18 & 18.0 \\
\hline & $\begin{array}{l}\text { Urinary tract } \\
\text { infection }\end{array}$ & 22 & 22.0 \\
\hline & \begin{tabular}{|l|} 
Puerperal sepsis \\
\end{tabular} & 1 & 1.0 \\
\hline & $\begin{array}{c}\text { Hospital acquired } \\
\text { pneumonia }\end{array}$ & 27 & 27.0 \\
\hline & $\begin{array}{c}\text { Methicillin } \\
\text { resistant } \\
\text { staphylococcus } \\
\text { aureus }\end{array}$ & 20 & 20.0 \\
\hline & No response & 12 & 12.0 \\
\hline \multirow{7}{*}{$\begin{array}{l}\text { Antibiotics used } \\
\text { to treat } \\
\text { nosocomial } \\
\text { infection }(\mathrm{N}=100)\end{array}$} & Piperacillin & 4 & 4.0 \\
\hline & Vancomycin & 26 & 26.0 \\
\hline & Imipenem & 3 & 3.0 \\
\hline & Ceftazidime & 19 & 19.0 \\
\hline & Linezolid & 22 & 22.0 \\
\hline & Others & 25 & 25.0 \\
\hline & Not recorded & 1 & 1.0 \\
\hline
\end{tabular}

\section{DISCUSSION}

Study participants were all young medical professionals. All the participants were familiar with Nosocomial Infections. Similar studies from the various parts of the world reported variable levels of knowledge of Nosocomial Infections among Health care workers. ${ }^{8-10}$ The different types of nosocomial infections cited were UTI, post-operative wound infections, respiratory tract infections, pneumonia, Ventilator Associated Pneumonia, and Pyoderma. Similar findings were reported by S. Masavkar et al where majority of the study participants were knowledgeable about the Nosocomial Infections. However in another study the knowledge of the study participants was very poor.11,12

The most prominent pathogens causing Nosocomial Infections mentioned by the doctors were Pseudomonas, Staphylococcus aureus, Acinetobacter baumannii, Escherichia coli, and others. These are similar to the list of organisms isolated in a study by U Kamat et al at Goa Medical College. ${ }^{7}$ This finding reveals that the study participants are well versed with the kind of organisms frequently isolated by the Department of Microbiology at their institution. In the current study, bacteria pseudomonas was reported as a major Nosocomial infectious agent. The most probable reason being that the majority of the study participants represented surgical specialities. Similar microorganisms were encountered by health professionals in other studies.2,13,14 The mode of transmission of Nosocomial Infections cited by medical professionals was direct contact with patients and staff, aerosols from patients, unsterile instruments and fomites. All doctors were aware of universal safety precautions and believed that Nosocomial Infections are a major concern to them in their respective practice and also agreed for its inclusion in Medical education syllabus. Majority of study participants practiced handwashing. In similar studies reported the handwashing practice varies from place to place. ${ }^{15-22}$ 
Majority of study participants regularly ensure sterile conditions while performing catheterization procedure and very few of them exited sterile portion of Operation Theatre (OT) along with OT footwears and gowns regularly. This kind of practice can increase the risk of infection to the patients being operated in OT. ${ }^{23}$ In a similar study, a higher proportion of study participants ensured sterile precautions before catheterization. ${ }^{24}$ Most of the doctors' wore gloves regularly for dressing. In another study less proportion of health care workers wore gloves to prevent infection. ${ }^{25-27}$

Half of the doctors recommended isolation of patient with Nosocomial Infections regularly. In another study by M Jain et al reported that $25 \%$ of study participants believed that isolation would help in prevention of Nosocomial Infections. ${ }^{28}$ Majority of the doctors regularly sent patient's tissue or fluid for culture and drug-sensitivity testing. Commonest nosocomial infection encountered by the medical professionals was Hospital acquired pneumonia, Urinary tract infection, Methicillin resistant staphylococcus aureus, Post-operative wound infection. Similar findings were reported by other researchers. ${ }^{29,30}$ In another study Nosocomial Infections reported was cholera which is not reported in the current study setting. ${ }^{9}$ Majority of the study participants mentioned that the antibiotics that could be employed for the treatment of Nosocomial Infections were Vancomycin, Linezolid, Ceftazidime, etc. A study done at Goa Medical College reported that isolates were sensitive to Methicillin, Rifampicin, co-trimoxazole, Teicoplanin, Vancomycin. ${ }^{7}$

\section{CONCLUSION}

Doctors had excellent knowledge about the Nosocomial Infections. Some deficiencies in the practice such as not ensuring sterile practices, exiting OT with OT footwear were areas of concern.

\section{Recommendations}

The medical school syllabus must include topic of Nosocomial Infections so that the future doctors are adequately equipped to handle such cases encountered in their regular practice.

\section{Limitation}

Only young medical professionals were interviewed hence the opinions of senior faculty is not taken into consideration. The sample size is purposive and small hence may be limited in the generalizability of the findings of the study.

\section{REFERENCES}

[1] Ducel G, Fabry J, Nicolle L. Prevention of hospitalacquired infections: a practical guide. $2^{\text {nd }}$ edn. Geneva, Switzerland: World Health Organization 2002: p. 1-64. doi: WHO/CDS/CSR/EPH/2002.12.64 p.

[2] Gupta P, Agrawal A. Correlation of infection of surgical wounds with pre - operative hospital stay in a medical college hospital. J Evol Med \& Dent Sci 2015;4(18):3065-70.

[3] Pyenson B, Murphy-Barron CM, Mirkin D, et al. Economic impact of hospital-acquired infections on hospitals. 2017: p. 1-37.

[4] Nair V, Sahni AK, Sharma D, et al. Point prevalence \& risk factor assessment for hospital-acquired infections in a tertiary care hospital in Pune, India. Indian J Med Res 2017;145(6):824-32.
[5] Ramasubramanian V, Iyer V, Sewlikar S, et al. Epidemiology of healthcare acquired infection - an Indian perspective on surgical site infection and catheter related blood stream infection. Indian J Basic Appl Med Res 2014;3(4):46-63.

[6] Kamat US, Ferreira AMA, Savio R, et al. Antimicrobial resistance among nosocomial isolates in a teaching hospital in Goa. Indian J Community Med 2008;33(2):89-92.

http://medind.nic.in/iaj/t08/i2/iajt08i2p89.pdf.

[7] Lauritsen J, Bruus M. EpiData (Version 3.1). A comprehensive tool for validated entry and documentation of data. 2008: p. 2. Accessed on August 13 , 2018.

http://www.epidata.dk/downloads/epdintro.pdf.

[8] Ocran I, Tagoe DNA. Knowledge and attitude of healthcare workers and patients on healthcare associated infections in a regional hospital in Ghana. Asian Pacific J Trop Dis 2014;4(2):135-9.

[9] Gupta A, Kapil A, Lodha R, et al. Knowledge, attitude and practice towards infection control among healthcare professionals. Natl Med J India 2013;26(1):59-60.

[10] Iliyasu G, Dayyab F, Habib ZG, et al. Knowledge and practices of infection control among healthcare workers in a tertiary referral center in North-Western Nigeria. Ann Afr Med 2016;15(1):34-40.

[11] Masavkar SP, Naikwadi AM. Knowledge, attitude and practice regarding nosocomial infections among general health practitioners and medical college students. Sch J Appl Med Sci SJAMS 2016;4(5F):18526. www.saspublisher.com. Accessed July 22, 2018.

[12] Sherah ASS, Jaafar MH. Assessment of infection control among health care workers in healthcare centers Sanaá, Yemen: cross-sectional study. Int J Public Heal Res 2015;5(2):597-605.

[13] Aftab HB, Zia B, Zahid MF, et al. Open forum infectious diseases knowledge, attitude, and practices of healthcare personnel regarding the transmission of pathogens via fomites at a tertiary care hospital in Karachi, Pakistan. Open Forum Infect Dis 2015;3(1): of v 208.

[14] Afolabi OT, Onipede AO, Omotayo SK, et al. Hospital acquired infection in Obafemi Awolowo University Teaching Hospital, lle-lfe, South-West Nigeria: a Ten year review (2000-2009). Sierra Leone J Biomed Res 2011;3(2):110-5.

[15] Alex-Hart BA, Opara PI. Hand washing practices amongst health workers in a teaching hospital. Am J Infect Dis 2011;7(1):8-15.

[16] Sharma R, Sharma M, Koushal V. Hand washing compliance among healthcare staff in Intensive Care Unit (ICU) of a multispecialty hospital of North India. J Hosp Adm 2012;1(2):27-33. https://doi.org/10.5430/jha.v1n2p27.

[17] Nair SS, Hanumantappa R, Hiremath SG, et al. Knowledge, Attitude, and Practice of Hand Hygiene among Medical and Nursing Students at a Tertiary Health Care Centre in Raichur, India. Article ID 608927, ISRN Prev Med 2014;2014:1-4. 
[18] Maheshwari V, Kaore NCM, Ramnani VK, et al. A study to assess knowledge and attitude regarding hand hygiene amongst residents and nursing staff in a tertiary health care setting of Bhopal city. J Clin Diagnostic Res 2014;8(8):DC04-7.

[19] Gulilat K, Tiruneh G. Assessment of knowledge, attitude and practice of health care workers on infection prevention in health institution Bahir Dar city administration. Sci J Public Heal 2014;2(5):38493. doi:10.11648/j.sjph.20140205.13.

[20] Suchitra JB, Devi LN. Impact of education on knowledge, attitudes and practices among various categories of health care workers on nosocomial infections. Indian J Med Microbiol 2007;25(3):181-7. www.ijmm.org.

[21] Diwan V, Gustafsson C, Klintz SR, et al. Understanding healthcare workers self-reported practices, knowledge and attitude about hand hygiene in a medical setting in rural India. PLoS One 2016;11(10):e0163347.

[22] Musu M, Lai A, Mereu NM, et al. Assessing hand hygiene compliance among healthcare workers in six Intensive Care Units. J Prev Med Hyg 2017;58(3):E231-E7.

[23] Mahumoud MH, Asaad AM. Surgical asepsis practices among or staff in King Khalid hospital, Najran. Int J Curr Res 2013;5(11):3461-73.

[24] Chauhan K. Knowledge attitude and practice towards infection control measures amongst medical students in a medical teaching tertiary care hospital. Int J Clin Med 2017;8(9):534-42. doi:10.4236/ijcm.2017.89050.
[25] Mythri H, Arun A, Kashinath KR. Perception and practice regarding infection control measures among healthcare workers in a tertiary center, South India. Journal Chem Pharm Res 2015;7(2):109-14.

[26] Yakob E, Lamaro T, Henok A. Knowledge, attitude and practice towards infection control measures among Mizan-Aman general hospital workers, South West Ethiopia. J Community Med Health Educ 2015;5(5):18. doi:10.4172/2161-0711.1000370.

[27] Unakal CG, Nathaniel A, Keagan B, et al. Assessment of knowledge, attitudes and practices towards infection prevention among healthcare workers in Trinidad and Tobago. Int J Community Med Public Heal 2017;4(7):2240-7. doi:10.18203/23946040.ijcmph20172813.

[28] Jain M, Dogra V, Mishra B, et al. Knowledge and attitude of doctors and nurses regarding indication for catheterization and prevention of catheter-associated urinary tract infection in a tertiary care hospital. Indian J Crit Care Med 2015;19(2):76-81.

[29] Narendranath VVGS, Asha, Rajan B. Epidemiology of hospital acquired infections among patients admitted in a tertiary care hospital, Bangalore. MSRUAS-JMC 2014;1(1):15-7.

http://www.msruas.ac.in/pdf_files/Publications/MCJ ournals/Sept2014/4.pdf. Accessed January 23, 2018.

[30] Balaban I, Tanir G, Timur OM, et al. Nosocomial infections in the general pediatric wards of a hospital in Turkey. Japan J Infect Dis 2012;65(5):318-21. 